\title{
Comparative Analysis of the Presence of THe NeW AND MODERN TECHNOLOGIES IN MICRO ENTERPRISES
}

\author{
Katarina Stavlic
}
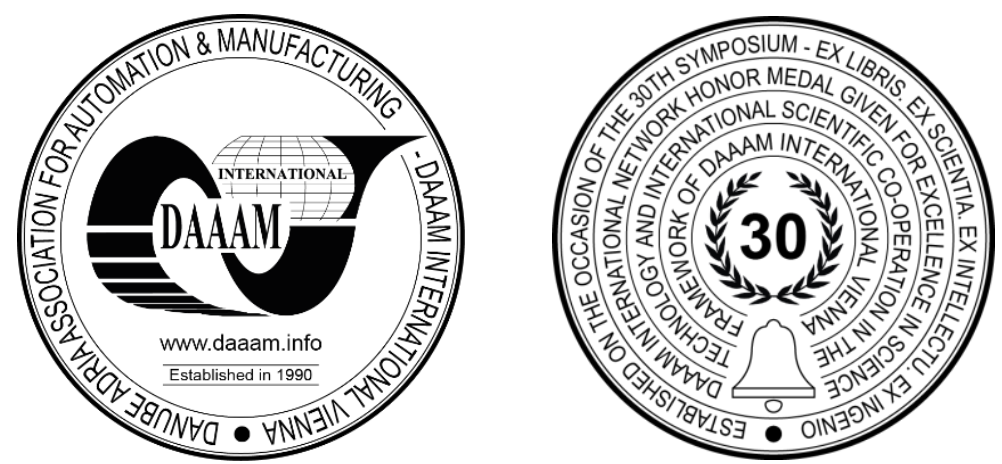

This Publication has to be referred as: Stavlic, K[atarina] (2020). Comparative Analysis of the Presence of the New and Modern Technologies in Micro Enterprises, Proceedings of the 31st DAAAM International Symposium, pp.09360942, B. Katalinic (Ed.), Published by DAAAM International, ISBN 978-3-902734-29-7, ISSN 1726-9679, Vienna, Austria

DOI: $10.2507 / 31$ st.daaam.proceedings. 130

\begin{abstract}
This research analyses the presence and application of new and modern technologies in micro-enterprises through the aspect of technology as a resource and a factor that affects business performance. The research has included a sample of 121 micro-entrepreneurs running their businesses in region Slavonia and Baranja in Croatia. The aim of this research is to present the results of empirical research about the present level of application of modern technologies in microenterprises, conducted on a sample of 121 micro-enterprises from the three activities: manufacturing, construction and agriculture, fisheries and forestry. Also, in this paper was made comparative analysis with research results conducted in 2016. on a similar sample of micro-enterprises. Here were applied appropriate statistical and mathematics methods for data collection, evaluation and analyzing. It was found that there is an increase of the presence of modern technologies in analyzed micro-enterprises.
\end{abstract}

Keywords: Micro-enterprises; New and modern technologies; Investments; Knowledge and skills; Slavonia and Baranja region

\section{Introduction}

Micro enterprises have a growing contribution to the economic growth of the Croatian economy and according to the Small Business Development Promotion Act, which complies with Commission Recommendation 2003/361 / EC of 6th of May 2003, represent natural or legal persons that yearly employ less than ten workers, realize a total annual income in the amount equivalent to EUR 2,000,000.00, or have total assets if they are profit tax payers, i.e. fixed assets if they are income tax payers in the amount equal to EU 2,000,000.00. [1]

Small and medium-sized enterprises in the Republic of Croatia have been recorded continuous growth and development for the last 20 years. Micro enterprises have a growing share in the total number of companies in the Republic of Croatia, but in 2018 compared to 2017 they recorded a decline in the share of employment, total revenues and exports, and from 2014 to 2018 average number of employees decreased. In 2017 and 2018, they achieved a positive consolidated financial result, with an increase in profit in 2018 by 7.2\%. [2] It can be seen that micro-enterprises have made progress in achieving financial results by comparing their contribution to the economy a few years ago. Five years ago, the data were as follows [3]: 
- They had a growing share in the overall number of enterprises in the Republic of Croatia (83.7\% in $2013,89.28 \%$ in $2014,89.05 \%$ in 2015 .),

- In 2014 they employed $24.38 \%$ of the overall number of employees in small, medium and large enterprises, and in 2015 they recorded an increase in employment of $1.26 \%$ and have employed a total of $24.44 \%$ of the overall number of employees in the enterprise,

- In 2015 compared to 2014, they had recorded overall revenue growth of $1.89 \%$, which represents $10.49 \%$ of general entrepreneur's turnover,

- In 2015 compared to 2014 , they had reduced the overall realized negative consolidated financial result of $3.20 \%$, which amounts to HRK $-2,344,403,000.00$.

These data indicate an increasing contribution of micro-enterprises to the Croatian economy, and the fact that a many micro-entrepreneurs have reduced the number of employees and their income. Compared to small and medium-sized enterprises, micro-enterprises have limited human, organizational, technical and financial resources. The constraints and obstacles to small businesses` growth have been the subject of research by Grimsholm and Poblete [9].

The results of their study as the main internal and external barriers to small business development are lack of access to finance, competition, trade barriers, managerial competencies, lack of skilled labor, low investment in research and development and new technologies. It can be assumed that companies can remove or reduce barriers to growth and development by ensuring access to finance, improving managerial competencies, educating and qualifying the workforce, and increasing investment in research and development, to ensure conditions for more innovative, competitive, and ultimately more successful businesses. According to Karić [8], the following resources are of the most significant importance for the development of a company:

1. Raw material resources - refer to raw materials from natural sources. They are related to the extractive industry.

2. Energy resources - in a broader sense, energy resources can be included in raw materials and refer to energy sources used in production processes (oil, gas, electricity, etc.).

3. Technical resources - refer to production capacities and require high investments and monitoring of technological development.

4. Technological resources - are essential for the development of propulsive activities and relate to knowledge and scientific-technical achievements applied in business.

5. Financial resources - represent the company's monetary assets that determine the company's financial capacity and affect the amount of investment in development.

6. Human resources - refer to the company`s human resources and include all the knowledge, skills and competencies of employees.

The problem in the business of micro-enterprises arises when some of the listed resources are missing, or there is not enough knowledge about their use. Due to the above, micro-enterprises have business problems, which is manifested by a reduction in the number of employees, a decrease in income and a negative financial result. According to the data mentioned above, it is evident that micro-enterprises in the Republic of Croatia are in a situation where there is a trend of decreasing the number of employees and decreasing revenues in the past few years.

If this trend continues, there is a possibility of more unsuccessful operations of micro-enterprises and disruption of micro-enterprises' contribution to the growth and development of the Croatian economy. This indicates a possible problem in enterprises' business and suggests the need for research and analysis of the presence of technology resources in micro enterprises as one of the factors of growth and development. The assumption in this research is that the applying of the new and modern technologies enables the improvement of operational business, which can result in a more successful business. Activities and methods by which new technologies can be introduced into the business of microenterprises can go through the following vehicles [4]:

- the interaction with suppliers and customers and the technical analysis of competitors products,

- $\quad$ acquisition of new equipment and machinery,

- the movement of personnel,

- $\quad$ interaction with research and development activities and with technology broker - extension services.

Following the above, this research collected data on the importance and impact of individual factors on business performance, applying of certain knowledge and skills of employees in micro-enterprises, and the types of investments in micro-enterprises. These data will form the basis for concluding the presence of new and modern technologies in microenterprises. One of the performance factors is new technologies and, therefore, the aim of this paper is to examine the presence of modern technologies in micro-enterprises. Based on the obtained results, conclusions will be adopted about the presence of modern technologies in micro-enterprises. 


\section{Research methodology}

\subsection{Research question}

Research material and research question are defined under the assumption that previous scientific research and expert analyses in the Republic of Croatia on Croatian micro-enterprises' business have not fully identified all the factors, causes and reasons for successful business of micro-enterprises. In order for micro-entrepreneurs to operate effectively, they must be aware of their internal and external barriers and limitations in which they operate and of their strengths and potentials, i.e., internal resources. Therefore, the emphasis in this paper is on the resource of technology. The fundamental research question is: What is the level of presence of resources of new and modern technologies in micro-enterprises and what is their impact on the business of micro-enterprises?

\subsection{Sample and data collection}

For the purposes of this paper, empirical research was conducted using an online survey questionnaire to determine the presence of modern technologies in micro-enterprises in the region of Slavonia and Baranja in agriculture, forestry and fisheries (A), manufacturing (C) and construction (F). To find a sample and data on micro-enterprises in five counties in the region of Slavonia and Baranja from the above activities, a database of business entities in the Republic of Croatia in the Digital Chamber, available on the website of the Croatian Chamber of Commerce, was used. According to the Small Business Development Encouragement Act [5], criteria for classifying enterprises were used to define the sample selection criteria, considering the dominant quantitative criteria for the number of employees and the amount of income generated.

The research population is micro-enterprises according to the following defined criteria:

- $\quad$ active companies that submitted the annual financial report for 2018

- the number of employees at the end of 2018 (from 0 to 9),

- total annual revenues generated in 2018 (up to HRK 15 million),

- their registered office is in one of the five counties of the region of Slavonia and Baranja, and

- include activities A, C and F according to the National Classification of Activities [6].

By filtering the database according to the above criteria, a total of 2474 micro-companies met these criteria in the region of Slavonia and Baranja. Information on e-mail addresses was requested via e-mail about the Croatian Chamber of Commerce and the Croatian Chamber of Trades and Crafts, but due to current legislation, they could not meet the author's request. E-mail data was obtained through an Internet search, which was a time-consuming activity and an obstacle and limitation to this research. Out of 2474 micro-enterprises, only 445 had a valid e-mail address, which is $17.98 \% .121$ entrepreneurs answered the survey and the obtained answer rate was $27.19 \%$, but the entrepreneurs did not answer certain questions, so the accepted answer rate for some questions is slightly lower. According to Pološki Vokić [7], this represents a satisfactory rate because the rate of return of $20 \%$ is often set in the world as a marginal rate of return.

The online survey questionnaire was created using LimeSurvey software to prepare and conduct an online survey. Questions related to the presence of the application of modern technologies were taken from the survey questionnaire from the research on the success factors of micro-enterprises in the Republic of Croatia [1], which was conducted in 2016. During the data processing, an increase in the number of employees was noticed in some companies compared to the end of 2018, but since the issues related to investments in technologies included the period of the previous three-year operation of micro-companies, the answers of these companies were considered. An online survey for this paper's purposes was conducted from 27 February 2020 to 15 July 2020. The advantages and disadvantages of the applied data collection methodology are reflected in the more difficult availability of micro-entrepreneur's online contact data, but a high percentage of complete responses.

To compare the data with the results from 2016, the results of the research on the success factors of micro-enterprises were used [1]. The method used was a survey using a highly structured questionnaire on a sample of the target population of micro-enterprises in the Republic of Croatia from three activities: processing industry, agriculture, forestry and fishing and construction industry, whose business headquarters are in the area of five counties that make up the region of Slavonia and Baranja, which are: Požega-Slavonia County, Osijek-Baranja County, Brod-Posavina County, Vukovar-Srijem County and Virovitica County. The sample consisted of 1,295 micro-enterprises that are active, have submitted annual financial reports for 2015 and in accordance with the Encouraging Small Business Development [5] belong to the category of micro-entities of small economy. A total of 112 micro-enterprises responded to the questionnaire, a survey was conducted by phone in June and July 2016. We used appropriate statistical and mathematical methods for the generation and interpretation of research results (descriptive statistics with graphical presentation of data, parametric and nonparametric statistics tests). The questionnaire was intended for micro-enterprises owners and entrepreneurs / managers in micro-enterprises, since these persons are most familiar with enterprise's business operations, especially when it comes to micro-enterprises with one or two employees. 
When processing data collected by survey research, it was used descriptive and inferential statistics procedures. Details of the sample and the responses to individual questions are described by means of response frequency, and for the questions that were asked on a scale of five categories of answers (questions that sought the agreement or indication of the intensity or frequency of certain actions) averages are also listed (arithmetic means).

\section{Results and Discussions}

The following descriptive results were obtained by applying appropriate statistical and mathematical methods. The descriptive statistics of the survey sample and the share of micro-enterprises surveyed by the county are presented in Table 1. To gain insight into the regional specifics of micro-enterprises business performance. A sample was made up of micro-enterprises from five counties that make up the region of Slavonia and Baranja. It can be noticed that the distribution of micro-entrepreneurs who responded to the survey in 2016 is evenly distributed by individual counties, while in the 2020 sample, there are larger deviations.

A higher response to the survey in Brod-Posavina County is visible. In 2016. the majority of responses were collected from micro-enterprises from the processing industry, a total of 63 companies $(56.3 \%)$, almost a third of those surveyed micro-enterprises are from the construction industry, 37 of them (33\%), while enterprises involved in agriculture, forestry and fisheries have the smaller share, i.e., 12 participants (10.7\%). According to the data on the structure of respondents by activities in 2020, there is a decrease in the share of manufacturing and construction, and an increase in the number of respondents from agriculture compared to the sample structure from 2016.

\begin{tabular}{|c|c|c|c|c|}
\hline Variables & $\begin{array}{c}\text { Number of micro- } \\
\text { enterprises }\end{array}$ & Share (in \%) & $\begin{array}{c}\text { Number of micro- } \\
\text { enterprises }\end{array}$ & Share (in \%) \\
\hline County & 2016. & 2016. & 2020. & 2020. \\
\hline Brod-Posavina & 27 & 24.1 & 53 & 43,8 \\
\hline Osijek-Baranja & 28 & 25 & 17 & 14,05 \\
\hline Poega-Slavonia & 10 & 8.9 & 28 & 23,14 \\
\hline Virovitica-Podravina & 21 & 18.8 & 10 & 8,27 \\
\hline Vukovar-Srijem & 26 & 23.2 & 13 & 10,74 \\
\hline Total & $\mathbf{1 1 2}$ & $\mathbf{1 0 0}$ & $\mathbf{1 2 1}$ & $\mathbf{1 0 0}$ \\
\hline Activities & 2016. & 2016. & 2020. & 2020. \\
\hline Agriculture, forestry and & 12 & 10.7 & 44 & 36,37 \\
\hline fisheries & 63 & 56.3 & 42 & 34,71 \\
\hline Manufacturing & 37 & 33 & 35 & 28,92 \\
\hline Construction & $\mathbf{1 1 2}$ & $\mathbf{1 0 0}$ & $\mathbf{1 2 1}$ & $\mathbf{1 0 0}$ \\
\hline Total & & &
\end{tabular}

Table 1. Descriptive statistics

\begin{tabular}{|c|c|c|c|c|}
\hline Year & Loss in business & Profit in business & No answer & Total \\
\hline 2016. & 45 & 59 & 8 & 112 \\
& $40,18 \%$ & $52,68 \%$ & $7,14 \%$ & $100,0 \%$ \\
\hline 2020. & 8 & 87 & 26 & 121 \\
& $6,61 \%$ & $71,9 \%$ & $21,49 \%$ & $100,0 \%$ \\
\hline
\end{tabular}

Table 2. Structure of micro-enterprises according to financial result

According to the structure of the sample from research in 2020, there is an increase in the number of surveyed companies that operated with a profit and an increase in the number of respondents who did not answer regarding the company`s financial result. Due to the smaller number of companies operating at a loss in the 2020 survey sample, it was not possible to perform nonparametric statistical tests to prove the correlation of the given variables with the business performance and it is not possible to make a comparison of all the results of these two surveys.

In the questionnaire, micro-entrepreneurs were asked to rate the importance and influence of several factors on their enterprise's current operations ( 1 - the least important / the least impact on success, 5 - the most important / the biggest impact on success). Table 3. presents the frequency of certain answers, as well as their arithmetic means. 


\begin{tabular}{|c|c|c|c|c|c|c|c|c|c|c|c|c|}
\hline \multirow[b]{2}{*}{ Factor } & \multicolumn{6}{|c|}{2016.} & \multicolumn{6}{|c|}{2020.} \\
\hline & 1 & 2 & 3 & 4 & 5 & $\bar{X}$ & 1 & 2 & 3 & 4 & 5 & $\bar{X}$ \\
\hline $\begin{array}{l}\text { Continuous } \\
\text { investment in } \\
\text { research and } \\
\text { development } \\
\end{array}$ & $\begin{array}{c}0 \\
0.0 \%\end{array}$ & $\begin{array}{c}5 \\
4.5 \%\end{array}$ & $\begin{array}{c}17 \\
15.3 \%\end{array}$ & $\begin{array}{c}30 \\
27.0 \%\end{array}$ & $\begin{array}{c}59 \\
53.2 \%\end{array}$ & 4.29 & $\begin{array}{c}8 \\
6,61 \%\end{array}$ & $\begin{array}{c}5 \\
4,13 \%\end{array}$ & $26,45 \%$ & $\begin{array}{c}34 \\
28,1 \%\end{array}$ & $\begin{array}{c}42 \\
34,71 \%\end{array}$ & 3,85 \\
\hline Innovations & $\begin{array}{c}0 \\
0.0 \%\end{array}$ & $\begin{array}{c}3 \\
2.7 \%\end{array}$ & $\begin{array}{c}16 \\
14.4 \%\end{array}$ & $\begin{array}{c}27 \\
24.3 \%\end{array}$ & $\begin{array}{c}65 \\
58.6 \%\end{array}$ & 4.39 & $\begin{array}{c}3 \\
2,48 \%\end{array}$ & $\begin{array}{c}8 \\
6,61 \%\end{array}$ & $\begin{array}{c}31 \\
25,62 \%\end{array}$ & $\mid \begin{array}{c}29 \\
23,97 \%\end{array}$ & $\begin{array}{c}50 \\
41,32 \%\end{array}$ & 3,94 \\
\hline $\begin{array}{c}\text { Modern } \\
\text { management } \\
\text { methods }\end{array}$ & $\begin{array}{c}2 \\
1.8 \%\end{array}$ & $\begin{array}{c}2 \\
1.8 \%\end{array}$ & $\begin{array}{c}40 \\
36.4 \%\end{array}$ & $\begin{array}{c}33 \\
30.0 \%\end{array}$ & $\begin{array}{c}33 \\
30.0 \%\end{array}$ & 3.85 & $\begin{array}{c}7 \\
5,79 \%\end{array}$ & $\begin{array}{c}8 \\
6,61 \%\end{array}$ & $\begin{array}{c}24 \\
19,83 \%\end{array}$ & $\begin{array}{c}43 \\
35,54 \%\end{array}$ & $\begin{array}{c}39 \\
32,23 \%\end{array}$ & 3,82 \\
\hline $\begin{array}{c}\text { Formal and } \\
\text { informal } \\
\text { employee } \\
\text { education and } \\
\text { training } \\
\end{array}$ & $\begin{array}{c}1 \\
0.9 \%\end{array}$ & $\begin{array}{c}2 \\
1.8 \%\end{array}$ & $\begin{array}{c}29 \\
26.1 \%\end{array}$ & $\begin{array}{c}27 \\
24.3 \%\end{array}$ & $\begin{array}{c}52 \\
46.8 \%\end{array}$ & 4.14 & $\begin{array}{c}0 \\
0,0 \%\end{array}$ & $\begin{array}{c}6 \\
4,96 \%\end{array}$ & $\begin{array}{c}19 \\
15,7 \%\end{array}$ & $\begin{array}{c}46 \\
38,02 \%\end{array}$ & $\begin{array}{c}50 \\
41,32 \%\end{array}$ & 4,13 \\
\hline $\begin{array}{l}\text { Application of } \\
\text { modern } \\
\text { technologies in } \\
\text { business } \\
\text { processes }\end{array}$ & $\begin{array}{c}1 \\
0.9 \%\end{array}$ & $\begin{array}{c}3 \\
2.7 \%\end{array}$ & $\begin{array}{c}15 \\
13.5 \%\end{array}$ & $\begin{array}{c}34 \\
30.6 \%\end{array}$ & $\begin{array}{c}58 \\
52.3 \%\end{array}$ & 4.31 & $\begin{array}{c}2 \\
1,65 \%\end{array}$ & $\begin{array}{c}6 \\
4,96 \%\end{array}$ & $\begin{array}{c}22 \\
18,18 \%\end{array}$ & $\begin{array}{c}39 \\
32,23 \%\end{array}$ & $\begin{array}{c}52 \\
42,98 \%\end{array}$ & 4,13 \\
\hline
\end{tabular}

Table 3. The importance and influence of individual factors on business operations

Data in Table 3. shows that innovation (arithmetic mean is 4,39) is considered the most important factor influencing a company's business success in 2016. While in 2020, micro-entrepreneurs believe that formal and informal employee education and training and application of modern technologies in business processes are the most important factors of business success (arithmetic mean is 4,13 ).

The least important factor in both studies is considered to be modern management methods. The one criterion for determining the presence of applying the new technologies in this paper is the application and use of knowledge and skills by employees in the business conduct of micro-enterprises. The question relating to the human resources asked the respondents to assess the application of the following knowledge and skills by employees in their micro-enterprises (1 never used, 5 - regularly used). The results are shown in Table 4.

\begin{tabular}{|c|c|c|c|c|c|c|c|c|c|c|c|c|}
\hline \multirow[b]{2}{*}{ Factor } & \multicolumn{6}{|c|}{2016.} & \multicolumn{6}{|c|}{2020 . } \\
\hline & 1 & 2 & 3 & 4 & 5 & $\overline{\boldsymbol{X}}$ & 1 & 2 & 3 & 4 & 5 & $\bar{X}$ \\
\hline Analytical skills & $\begin{array}{c}14 \\
12.5 \% \\
\end{array}$ & $\begin{array}{c}18 \\
16.1 \% \\
\end{array}$ & $\begin{array}{c}38 \\
33.9 \% \\
\end{array}$ & $\begin{array}{c}25 \\
22.3 \% \\
\end{array}$ & $\begin{array}{c}17 \\
15.2 \% \\
\end{array}$ & 3.12 & $\begin{array}{c}15 \\
12,4 \% \\
\end{array}$ & $\begin{array}{c}19 \\
15,7 \% \\
\end{array}$ & $\begin{array}{c}40 \\
33,06 \%\end{array}$ & $\begin{array}{c}32 \\
26,45 \%\end{array}$ & $\begin{array}{c}15 \\
12,4 \% \\
\end{array}$ & \\
\hline $\begin{array}{l}\text { Use of foreign } \\
\text { languages }\end{array}$ & $\begin{array}{c}39 \\
35.1 \% \\
\end{array}$ & $\begin{array}{c}39 \\
35.1 \% \\
\end{array}$ & $\begin{array}{c}20 \\
18.0 \% \\
\end{array}$ & $\begin{array}{c}7 \\
6.3 \% \\
\end{array}$ & $\begin{array}{c}6 \\
5.4 \% \\
\end{array}$ & 2.12 & $\begin{array}{c}19 \\
15,7 \% \\
\end{array}$ & $\begin{array}{c}20 \\
16,53 \% \\
\end{array}$ & $\begin{array}{c}33 \\
27,27 \%\end{array}$ & $\begin{array}{c}32 \\
26,45 \%\end{array}$ & $\begin{array}{c}17 \\
14,05 \% \\
\end{array}$ & 2,98 \\
\hline Negotiating skills & $\begin{array}{c}6 \\
5.4 \% \\
\end{array}$ & $\begin{array}{c}12 \\
10.8 \% \\
\end{array}$ & $\begin{array}{c}48 \\
43.2 \% \\
\end{array}$ & $\begin{array}{c}27 \\
24.3 \% \\
\end{array}$ & $\begin{array}{c}18 \\
16.2 \% \\
\end{array}$ & 3.35 & $\begin{array}{c}8 \\
6,61 \% \\
\end{array}$ & $\begin{array}{c}12 \\
9,92 \%\end{array}$ & $\begin{array}{c}36 \\
29,75 \%\end{array}$ & $\begin{array}{c}30 \\
24,79 \%\end{array}$ & \begin{tabular}{|c|}
35 \\
$28,93 \%$ \\
\end{tabular} & 3,5 \\
\hline Sales skills & $\begin{array}{c}2 \\
1.8 \% \\
\end{array}$ & $\begin{array}{c}16 \\
14.4 \% \\
\end{array}$ & $\begin{array}{c}34 \\
30.6 \% \\
\end{array}$ & $\begin{array}{c}26 \\
23.4 \% \\
\end{array}$ & $\begin{array}{c}33 \\
29.7 \% \\
\end{array}$ & 3.65 & $\begin{array}{c}8 \\
6,61 \% \\
\end{array}$ & $\begin{array}{c}10 \\
8,26 \% \\
\end{array}$ & $\begin{array}{c}24 \\
19,83 \% \\
\end{array}$ & $\begin{array}{c}40 \\
33,06 \%\end{array}$ & $\begin{array}{c}39 \\
32,23 \% \\
\end{array}$ & 3,69 \\
\hline $\begin{array}{l}\text { IT and computer } \\
\text { skills }\end{array}$ & $\begin{array}{c}5 \\
4.5 \% \\
\end{array}$ & $\begin{array}{c}13 \\
11.8 \%\end{array}$ & $\begin{array}{c}36 \\
32.7 \%\end{array}$ & $\begin{array}{c}31 \\
28.2 \%\end{array}$ & $\begin{array}{c}25 \\
22.7 \%\end{array}$ & 3.53 & $\begin{array}{c}6 \\
4,96 \%\end{array}$ & $\begin{array}{c}14 \\
11,57 \%\end{array}$ & $\begin{array}{c}36 \\
29,75 \%\end{array}$ & $\begin{array}{c}37 \\
30,58 \%\end{array}$ & $\begin{array}{c}28 \\
23,14 \%\end{array}$ & 3,53 \\
\hline Project management & $\begin{array}{c}10 \\
9.1 \% \\
\end{array}$ & $\begin{array}{c}10 \\
9.1 \% \\
\end{array}$ & $\begin{array}{c}25 \\
22.7 \% \\
\end{array}$ & $\begin{array}{c}25 \\
22.7 \% \\
\end{array}$ & $\begin{array}{c}40 \\
36.4 \% \\
\end{array}$ & 3.68 & $\begin{array}{c}23 \\
19,01 \% \\
\end{array}$ & $\begin{array}{c}16 \\
13,22 \% \\
\end{array}$ & $\begin{array}{c}33 \\
27,27 \% \\
\end{array}$ & $\begin{array}{c}20 \\
16,53 \%\end{array}$ & $\begin{array}{c}29 \\
23,97 \% \\
\end{array}$ & 3,06 \\
\hline $\begin{array}{l}\text { Knowledge of } \\
\text { modern methods for } \\
\text { improving } \\
\text { business processes } \\
\text { (Just in Time, } 5 \mathrm{~S}, \\
\text { Kaizen, etc.) }\end{array}$ & $\begin{array}{c}16 \\
14.5 \%\end{array}$ & $\begin{array}{c}14 \\
12.7 \%\end{array}$ & $\begin{array}{c}31 \\
28.2 \%\end{array}$ & $\begin{array}{c}17 \\
15.5 \%\end{array}$ & $\begin{array}{c}32 \\
29.1 \%\end{array}$ & 3.32 & $\begin{array}{c}54 \\
44,63 \%\end{array}$ & $\begin{array}{c}22 \\
18,18 \%\end{array}$ & $\begin{array}{c}26 \\
21,49 \%\end{array}$ & $\begin{array}{c}10 \\
8,26 \%\end{array}$ & $\begin{array}{c}9 \\
7,44 \%\end{array}$ & 2,1 \\
\hline
\end{tabular}

Table 4. The application of knowledge and skills by employees of micro-enterprises 
The data shown in Table 4. show that most of the micro-enterprises skills in 2016 were project management skills, and the arithmetic mean was 3.68. Other commonly used skills are sales skills (intermediate 3.65) and computer and computer skills (intermediate 3.53). The least applied skills are knowledge of foreign languages. In 2020, sales skills were most commonly used, while IT and computer skills and negotiation skills were the next most frequently used. Comparing the data, it can be seen that the application of analytical skills, project management and knowledge of modern methods for improving business processes has decreased.

Based on the obtained results, it can be concluded that Croatian micro-entrepreneurs have a satisfactory level of formal and non-formal education. In performing their business activities, they use skills related to the application of new technologies.

The next question in the survey questionnaire related to the level of investment in the past three years in various activities that encourage business. Respondents were offered activities in which they could invest and which they could rate on a scale of 1 to 5, with a score of 1 meaning that no investment was made at all, and a score of 5 meaning that there was significant investment. Table 5 lists the frequencies of individual responses, as well as their arithmetic means.

\begin{tabular}{|c|c|c|c|c|c|c|c|c|c|c|c|c|}
\hline \multirow[b]{2}{*}{ Factor } & \multicolumn{6}{|c|}{2016.} & \multicolumn{6}{|c|}{2020.} \\
\hline & 1 & 2 & 3 & 4 & 5 & $\bar{X}$ & 1 & 2 & 3 & 4 & 5 & $\overline{\boldsymbol{X}}$ \\
\hline $\begin{array}{l}\text { Purchase of } \\
\text { machinery, } \\
\text { equipment, } \\
\text { software or } \\
\text { licenses }\end{array}$ & $\begin{array}{c}8 \\
7,1 \%\end{array}$ & $\begin{array}{c}10 \\
8,9 \%\end{array}$ & $\begin{array}{c}19 \\
17,0 \%\end{array}$ & $\begin{array}{c}27 \\
24,1 \%\end{array}$ & $\begin{array}{c}48 \\
42,9 \%\end{array}$ & 3,87 & $\begin{array}{c}6 \\
4,96 \%\end{array}$ & $\begin{array}{c}13 \\
10,74 \%\end{array}$ & $\begin{array}{c}20 \\
16,53 \%\end{array}$ & $\begin{array}{c}34 \\
28,1 \%\end{array}$ & $\begin{array}{c}48 \\
39,67 \%\end{array}$ & 3,88 \\
\hline $\begin{array}{l}\text { Improving } \\
\text { organizatio } \\
\text { nal or } \\
\text { business } \\
\text { processes }\end{array}$ & $\begin{array}{c}6 \\
5,4 \%\end{array}$ & $\begin{array}{c}7 \\
6,3 \%\end{array}$ & $\begin{array}{c}30 \\
26,8 \%\end{array}$ & $\begin{array}{c}34 \\
30,4 \%\end{array}$ & $\begin{array}{c}35 \\
31,3 \%\end{array}$ & 3,76 & $\begin{array}{c}13 \\
10,74 \%\end{array}$ & $\begin{array}{c}18 \\
14,88 \%\end{array}$ & $\begin{array}{c}30 \\
24,79 \%\end{array}$ & $\begin{array}{c}40 \\
33,06 \%\end{array}$ & $\begin{array}{c}20 \\
16,53 \%\end{array}$ & 3,34 \\
\hline $\begin{array}{l}\text { Design of } \\
\text { products } \\
\text { and } \\
\text { services } \\
\end{array}$ & $\begin{array}{c}26 \\
23,2 \%\end{array}$ & $\begin{array}{c}15 \\
13,4 \%\end{array}$ & $\begin{array}{c}45 \\
40,2 \%\end{array}$ & $\begin{array}{c}15 \\
13,4 \%\end{array}$ & $\begin{array}{c}11 \\
9,8 \%\end{array}$ & 2,73 & $\begin{array}{c}18 \\
14,88 \%\end{array}$ & $\begin{array}{c}18 \\
14,88 \%\end{array}$ & $\begin{array}{c}37 \\
30,58 \%\end{array}$ & $\begin{array}{c}26 \\
21,49 \%\end{array}$ & $\begin{array}{c}22 \\
18,18 \%\end{array}$ & 3,19 \\
\hline $\begin{array}{l}\text { Research } \\
\text { and } \\
\text { developme } \\
\text { nt (R\&D) }\end{array}$ & $\begin{array}{c}17 \\
15,2 \%\end{array}$ & $\begin{array}{c}15 \\
13,4 \%\end{array}$ & $\begin{array}{c}44 \\
39,3 \%\end{array}$ & $\begin{array}{c}26 \\
23,2 \%\end{array}$ & $\begin{array}{c}10 \\
8,9 \%\end{array}$ & 2,97 & $\begin{array}{c}38 \\
31,4 \%\end{array}$ & $\begin{array}{c}27 \\
22,31 \%\end{array}$ & $\begin{array}{c}30 \\
24,79 \%\end{array}$ & $\begin{array}{c}16 \\
13,22 \%\end{array}$ & $\begin{array}{c}10 \\
8,26 \%\end{array}$ & 2,53 \\
\hline $\begin{array}{c}\text { Company's } \\
\text { reputation } \\
\text { and } \\
\text { branding, } \\
\text { including } \\
\text { web design }\end{array}$ & $\begin{array}{c}11 \\
9,8 \%\end{array}$ & $\begin{array}{c}15 \\
13,4 \%\end{array}$ & $\begin{array}{c}44 \\
39,3 \%\end{array}$ & $\begin{array}{c}27 \\
24,1 \%\end{array}$ & $\begin{array}{c}15 \\
13,4 \%\end{array}$ & 3,18 & $\begin{array}{c}20 \\
16,53 \%\end{array}$ & $\begin{array}{c}25 \\
20,66 \%\end{array}$ & $\begin{array}{c}23 \\
19,01 \%\end{array}$ & $\begin{array}{c}33 \\
27,27 \%\end{array}$ & $\begin{array}{c}20 \\
16,53 \%\end{array}$ & 3,13 \\
\hline $\begin{array}{l}\text { Employee } \\
\text { training } \\
\text { and } \\
\text { education }\end{array}$ & $\begin{array}{c}25 \\
22,3 \%\end{array}$ & $\begin{array}{c}9 \\
8,0 \%\end{array}$ & $\begin{array}{c}43 \\
38,4 \%\end{array}$ & $\begin{array}{c}24 \\
21,4 \%\end{array}$ & $\begin{array}{c}11 \\
9,8 \%\end{array}$ & 2,88 & $\begin{array}{c}19 \\
15,7 \%\end{array}$ & $\begin{array}{c}21 \\
17,36 \%\end{array}$ & $\begin{array}{c}32 \\
26,45 \%\end{array}$ & $\begin{array}{c}31 \\
26,62 \%\end{array}$ & $\begin{array}{c}18 \\
14,88 \%\end{array}$ & 3,07 \\
\hline
\end{tabular}

Table 5. Types of investments in micro-enterprises

From the above data, it can be seen that the surveyed micro-enterprises (2016) invested the most in the purchase of machinery, equipment, software or licenses. $67 \%$ of respondents gave this activity a score of 4 or 5 , so the arithmetic mean is 3.87. Investments follow this in improving organizational or business processes $(\bar{X}=3.76)$, investments in company reputation and branding $(\bar{X}=3.18)$, investments in research and development $(\bar{X}=2.97)$, while the lowest investment in product and service design $(\bar{X}=2.73)$ with $26 \%$ of respondents giving a grade of 1 (no investment at all) and investment in employee training and development $(\bar{X}=2.88)$ for which a quarter of respondents $(25 \%$ of them) gave a grade of 1 . The surveyed micro-enterprises (2020) also invested the most in the procurement of machinery, equipment, programs or licenses and the arithmetic mean is 3.88. Then, investments in the improvement of organizational or business processes follow $(\bar{X}=3.34)$, while the least was invested in research and development $(\bar{X}=2.53)$.

Comparing the presented data, it can be seen that the highest investments in both samples are in the procurement of machinery, equipment, software or licenses. The increase in the arithmetic mean value is visible in investments in product and service design and employee training and education. While there is a visible reduction in investment in improving organizational or business processes, research and development, and the company's reputation and branding. 


\section{Conclusions and recommendations}

The results of this research indicate the presence of modern technologies in the business of micro enterprises through investments in the acquisition of new technologies, the application of IT and computer skills and the fact that micro entrepreneurs consider the most important factor of success application of modern technologies in business processes and formal and informal employee education and training. According to the presented data in table 3 , it can be concluded that according to the answers of micro-entrepreneurs, the application of modern technologies for their business is extremely important. They assessed as the most important factor of business success (arithmetic mean 4.13) in the 2020 survey, and formal and informal employee education and training (arithmetic mean 4,13). The application of new technologies in business depends on the expertise of human resources. According to the comparative analysis of the results on the application of knowledge and skills of micro-enterprises employees, it is evident that the least used knowledge of modern methods for improving business processes (Just in Time, 5S, Kaizen, etc.), arithmetic mean is 2.17 in 2020 . And that there has been a reduction in the arithmetic mean of analytical skills application and project management. From the above, it can be concluded that these results reflect the mentioned trend of decreasing the number of employees in microenterprises. However, in order to achieve better business performance and ensure more competitive business, in the future, it is necessary to improve the knowledge and application of analytical skills, IT and computer skills and project management in business operations. Suppose entrepreneurs do not turn in that direction. In that case, this could pose a difficulty for micro-enterprises in the future due to the increasing application of modern technologies in business and the environment. Therefore, entrepreneurs can be advised to constantly invest in skills and knowledge to improve their products, sales and other capabilities; and be innovative and competitive. Based on a comparison of the results (table 5), it can be concluded that micro-entrepreneurs have invested the most in purchase of machinery, equipment, software or licenses in both analysed periods. They invested the least in product and service design in 2016, while in 2020, there was the least investment in research and development. Micro entrepreneurs have reduced investment in improving organizational or business processes, in research and development, and the company's reputation and branding in 2020 compared to 2016. Due to limited human resources, micro-enterprises have made the largest investments in equipment, machinery and modern technologies to remain competitive and sustainable in the market.

This study provides a theoretical contribution to the development of scientific thought on the specifics of micro enterprises, the development of scientific thought on the application of modern technologies in micro enterprises, and the results of empirical research on the application of new technologies in micro enterprises. In the applicative sense, the expected contribution to the economic science of this research arises from the possibility of applying the results of empirical research in order to improve the business of existing micro enterprises. The limitation of this study is that the samples included micro-enterprises from one region and from three sectors. The results can be the basis for future research, including micro-enterprises from all over the Republic of Croatia and from several sectors, which would allow more accurate estimates of the presence of new and modern technologies in micro-enterprises.

Further research on the operations of micro-enterprises can focus on the entire territory of the Republic of Croatia and all sectors to investigate whether there are any specifics in the business operations of micro-entrepreneurs in individual counties, certain regions in the Republic of Croatia and in individual sectors. This research identified the presence of the new and modern technologies in micro-enterprise in the Slavonia and Baranja region.

\section{References}

[1] Štavlić, K. (2016). Success factors of micro enterprises in the Republic of Croatia, Čimbenici uspješnosti mikro poduzeća u Republici Hrvatskoj, Ph.D. Dissertation, Faculty of Economics, Josip Juraj Strossmayer University of Osijek, Croatia

[2] Štavlić, K. (2020). Analysis of the innovativity of Croatian micro entrepreneurs, Proceedings of the 7th International Conference "Vallis Aurea" Focus on: Research \& Innovation, 24-26 September 2020, Požega, Croatia, ISSN 1847 8204, ISBN 978-3-902734-26-6, Katalinic, B. (Ed.), pp. 603-611, Polytechnic in Pozega, DAAAM International Vienna, Požega, Vienna

[3] http://www.400naj.com/ (2015) Economic journal, Privredni vjesnik, 400 biggest Croatian companies in 2014, (3888), Accessed on: 2020-09-12

[4] http://www.assembly.coe.int/nw/xml/XRef/X2H-Xref-ViewHTML.asp?FileID=8798\&lang=en /1999). Committee on Science and Technology, New technologies in small and medium-sized enterprises (SMEs), Accessed on: 202009-29

[5] Small Business Development Encouragement Act (2016). National newspapers, Narodne novine no. 29/02, 63/07, 53/12, 56/13, 121/16, Art. 3, Available from: https: //www.zakon.hr/z/527/Zakon-o-poticanju-razvoja-maloggospodarstva, Accessed on: 2020-09-15

[6] https://narodne-novine.nn.hr/clanci/sluzbeni/2007_06_58_1870.html, National Occupational Classification, Nacionalna klasifikacija djelatnosti 2007. - NKD 2007, NN 58/2007, Accessed on: 2020-09-30

[7] Pološki Vokić, N. (2004). Human resources management in large Croatian companies. Economic review, 55(5-6), 455-478, Available from: https://hrcak.srce.hr/16299, Accessed on: 2020-09-30

[8] Karić, M. (2005). Business economics, Ekonomika poduzeća, Josip Juraj Strossmayer University of Osijek, Faculty of Economics, ISBN 953-6073-08-0, Osijek

[9] Grimsholm, E., Poblete, L. (2010). Internal and External factors hampering SME growth -A qualitative case study of SMEs in Thailand - dissertation. Available from: https://uu.divaportal.org/smash/get/diva2:323837/FULLTEXT01.pdf, Accessed on: 2020-10-04 